\title{
"To TAKe Were to PuRloin": SEXUAlity IN THE NARRATIVE Poems OF Christina RossetTI
}

\author{
FAHRÏ ÖZ
}

Feminist thinkers have always been interested in the way the female body is "talked about, classified, disciplined, invaded, destroyed, altered, decorated, pleasured, ... and more". ${ }^{1}$ And the Victorian age appears to be a time in which the female body was severely disciplined, partly due to an unprecedented proliferation of discourses on sex in medicine, law, and religion. As the works of William Acton and W.R. Greg demonstrate, women were denied jouisance and were confined within domesticity, marriage and motherhood. ${ }^{2}$

However, women were banned not only from sexual pleasure but also from textual pleasure - the pleasure of authoring texts. The literary canon, which operated throughout the publishing industry, anthologies and critics, belittled women's writings - especially poetry - by demeaning their creations as feminine, domestic, and insignificant. Under such circumstances, one cannot expect a female Victorian poet to give vent to pent-up aspirations and desires, especially to sexual ones. This essay endeavours to demonstrate the way Christina Rossetti deals with sexual matters through metaphors and symbols based on flowers and fruit in her two long narrative poems, "Goblin Market" (1862) and "The Prince's Progress" (1866). ${ }^{3}$

\footnotetext{
${ }^{1}$ Barbara Brook, Feminine Perspectives on the Body, London, 1999, 2.

${ }^{2}$ See Frank Mort, Dangerous Sexualities: Medico-Moral Politics in England since 1830, London, 2000, 61; and Krista Lysack, "The Economy of Ecstasy in Christina Rossetti's 'Monna Innominata'”, Victorian Poetry, XXXVI/4 (Winter 1998), 1.

3 All the quotations of Christina Rossetti's poems are from The Complete Poems of Christina Rossetti, a Variorum Edition, ed. R.W. Crump, 3 vols, Baton Rouge: LA, 1990 ("Goblin Market", I, 11-26; "The Prince's Progress", I, 95-110). See also Christina Rossetti, The Complete Poems, Text by R.W. Crump and Notes and Introduction by Betty S. Flowers, Penguin, 2001, 5-20 and 89-104.
} 
The female body and sexuality plays an undeniably important role in Rossetti's fantastic narrative poem "Goblin Market". At first glance the poem reads like a fairy tale: two sisters, Laura and Lizzie, come across goblin men with beast-like forms selling fruit at twilight. The goblins manage to cajole Laura into buying their strange fruit. After tasting it, she pines away in a state of addiction. Lizzie decides to redeem her sister by an act of self-sacrifice. She finds the goblin men, who attack her, squeezing the juices of their fruit into her closed mouth. She comes home immersed in fruit juice. Laura kisses her, sucking the juice on her sister's body, which helps her recover. The poem ends in a peaceful atmosphere in which the two sisters, who are now mothers, relate their experiences to their daughters.

Despite its seeming innocence and simplicity, "Goblin Market" has led to various interpretations. Rod Edmond makes an inventory of such readings as

a Christian allegory; a feminist Christian allegory with a female figure; an allegory of sexual desire; a female rites of passage poem; a lesbian manifesto; a poem about the erotic life of children; a metaphoric statement about patterns of social destructiveness in Victorian England; and in psychoanalytic terms as a power struggle between mothers and children. ${ }^{4}$

Kooistra, who analyses various illustrations of "Goblin Market" such as those in Playboy, which turn the poem into pornographic material, claims that the poem is "about both female relationship and sexual exchange". 5 However, D.M.R. Bentley suggests that "Goblin Market" was written for merely didactic purposes, to be read aloud to "fallen women" at Highgate, as a warning about sexuality. ${ }^{6}$

This plethora of interpretations springs from the evasive and sexually charged content of the poem. ${ }^{7}$ Whatever the interpretation might be, the

\footnotetext{
${ }^{4}$ Rod Edmond, Affairs of the Hearth: Victorian Poetry and Domestic Narrative, London, 1988, 170.

${ }^{5}$ Lorraine Janzen Kooistra, "Visualizing the Fantastic Subject: 'Goblin Market' and the Gaze", in The Culture of Christina Rossetti: Female Poetics and Victorian Contexts, eds Mary Arseneau, Anthony H. Harrison and Lorraine Janzen Kooistra, Athens: OH, 1999, 162.

6 D.M.R. Bentley, "The Meretricious and the Meritorious in Goblin Market: A Conjecture and an Analysis", in The Achievement of Christina Rossetti, ed. David A. Kent, Ithaca: NY, 1987, 58-66.

${ }^{7}$ For further readings of the poem, see the Britta Zangen's article in this volume,
} 
centrality of the female body in "Goblin Market" cannot be ignored. The poem is open to a reading as an adult erotic fantasy because consuming fruit has sexual connotations. According to Michie, eating is intimately related to sexual appetite in the Victorian age; and Victorian sex manuals constantly equate food, especially certain types of food, with lust. This conviction was so strong that excessive appetites of all kinds were considered to lead directly to sexual disorders. For example, it was believed consuming salt and spice made the body "more and more heated, whereby the desire for venereal embraces is very great". 8

As Gilbert observes, fruit, which plays an important role in the poem, has been seen as a symbol of sexuality, reproduction and regeneration in religious and secular texts - ranging from the Genesis to D.H. Lawrence's Birds, Beasts and Flowers: "In countless folk narratives fearful metamorphoses begin with the ingestion of alien substance, and Judeo-Christian mythology itself, of course, starts with such a meal of poison fruit." Keats' "La Belle Dame Sans Merci", Tennyson's "Lotos Eaters", and the folk ballad "Lord Randal" deal with transformations that begin with eating. Rossetti reverses this motif, because in all these earlier examples the eater is a male. In "Goblin Market", however, the fruit is consumed by female characters. The fruit, which acts as an igniter of a transformation in the poem, is given in a startlingly wide inventory (11. 514):

Apples and quinces,

Lemons and oranges,

Plump unpecked cherries,

Melons and raspberries,

Bloom-down-cheeked peaches,

Swart-headed mulberries,

Wild free-born cranberries,

Crab-apples, dewberries,

Pine-apples, blackberries,

Apricots, strawberries ....

\footnotetext{
"Christina Rossetti's 'Goblin Market': The Eroticism of Female Mystics" (pages 247-57 above).

${ }^{8}$ Helena Michie, The Flesh Made Word: Female Figures and Women's Bodies, New York, 1987, 15.

${ }^{9}$ Sandra M. Gilbert, Acts of Attention: The Poems of D.H. Lawrence, Carbondale and Edwardsville, 1990, 335.
} 
The wide variety of fruit that Rossetti lists might even baffle a professional greengrocer in a huge supermarket. The catalogue of such sexually suggestive fruit in the poem alludes to a postlapsarian world: "If the first fruit of the goblin as well as satanic temptation is the allusive apple, the second (the quince) and the twenty-first (the pear) belong to the apple genus." "The word "fruit" is almost synonymous with original $\sin$. As Menke indicates, the $O E D$ entry for the word "fruit" suggests not only physical botanical products but also material gain and offspring as in the phrase "the fruit of the womb". "Nor should one forget that the Latin source of "fruit", fructus, means "enjoyment". The use of fruit is also significant because the globe-like fruit connotes testicles, which are known to be the source of virile power. Rossetti employs an astounding list of fruit in order to foreground their irresistible power and symbolic value - sexual appetite and pleasure. Indeed, the fact that nearly half of the goblin fruit are not grown in England makes them even more attractive and tempting.

Above all, the poet's deployment of such a deluge of fruit suggests that the poem has a quasi-pornographic content. As Marcus points out very clearly "the world of pornography is a world of plenty. In it all men are infinitely rich in substance, all men are limitlessly endowed with that universal fluid currency which can be spent without loss." ${ }^{\prime 2}$ The extravagant display of the goblin fruit accentuates the lavish sexual power and activity of the vendors. They are never short of fruit; they appear again and again with their sexually suggestive merchandise, ready to ravish their female clientele.

The fruit list is reiterated in the section where Lizzie visits the goblins to purchase fruit for her ailing sister, a repetition by means of which Rossetti foregrounds the sexual and transforming quality of the fruit. However, in "Goblin Market", by its association with the goblins, fruit is presented as a source of barrenness and illness due to its association with the goblins, which is why Lizzie warns Laura not to "peep at goblin men" (1. 49). Inherent in her warning is the idea and dangers of voyeurism, and, by asking her to look away from the eerie yet enticing creatures, Lizzie wants Laura to repress her sexual appetite. Like well-

\footnotetext{
${ }^{10}$ Sharon Smulders, Christina Rossetti Revisited, London, 1996, 35.

11 Richard Menke, "The Political Economy of Fruit", in The Culture of Christina Rossetti, 106.

12 Steven Marcus, The Other Victorians: A Study of Sexuality and Pornography in MidNineteenth-Century England, New York, 1966, 22.
} 
brought-up young Victorian women, she wishes to remain an object of gaze, or, at least, is content to be so, rather than a subject gazing herself.

Laura is lured by these strange vendors because she fails to realize that in the market women are not the buyers, but the "bought". In fact the merchandise is not fruit but the female body. The goblins hawk their goods repeating "come buy, come buy" all the time. While "buying" refers to a commercial activity, "coming" alludes to having an orgasm; but this orgasmic allusion is intertwined with death. The issue of sex is also almost synonymous with physical death or ailment as in the case of Jeanie, the maiden who had died after succumbing to the call of goblins. Sexual pleasure is almost a taboo and a transgression - when it is associated with the female body, a transgression. In her encounter with the goblins, Laura sheepishly confesses that

\footnotetext{
"Good folk, I have no coin;

To take were to purloin:

I have no copper in my purse,

I have no silver either ...."
}

The idea of taking or spending suggests not only economic power but also sexual pleasure as a man's privilege. Due to the economic and sexual values of the age women cannot "spend", cannot have an orgasm. ${ }^{13}$

Eating the fruit produces devastating results in Laura's body and mind, because, in a sense, she loses her virginity and wants to have sex again. Normally in Victorian literature a woman who loses her virginity out of wedlock surrenders her pure exchange value and becomes either a prostitute like Dante Gabriel Rossetti's Jenny or a repentant woman like Elizabeth Gaskell's Ruth. However, Laura becomes neither. She does not repent, because she wants to have access to sexual pleasure again, while a prostitute does not look for pleasure per se. The goblins do not appear to Laura after she has first eaten the fruit, because, if they were to do so, it would imply that they admit that as a woman she derives pleasure from sexual intercourse. Since she is deprived of sexual pleasure, she suffers a physical transformation, as a consequence of which

13 For a consideration of the sexual meaning of the word "spending" and its use in Christina Rossetti's poetry, see C.C. Barfoot, “Thus Only in a Dream': Appetite in Christina Rossetti's Poetry", in Tradition and the Poetics of Self in Nineteenth-Century Women's Poetry, ed. Barbara Garlick, Amsterdam and New York, 2002, 146-49. 
Her hair grew thin and gray;

She dwindled, as the full moon doth turn

To swift decay and burn

Her fire away.

She stops eating and begins to neglect her household duties, which is the only kind of labour she is associated with - her refusal to eat being related to her sense of dishonour and her desire to suppress her sexual hunger, which can also be taken as a symptom of a sexually transmitted disease or a guilty conscience. In her delirium Laura

thought of Jeanie in her grave,

Who should have been a bride;

But who for joys brides hope to have

Fell sick and died

In her gay prime, ...

Jeanie's story appears in the text as an embedded narrative that needs to be kept at a distance and mentioned only briefly since it involves perishing as a result of sexual indulgence.

Half way through the poem (lines 320 onwards), the focalizer becomes Lizzie, who sets out to redeem her sister. Lizzie puts "a silver penny in her purse" (1. 324), assuming that she can play the game according to the rules of the market. However, she is mistaken because the goblins will not accept her as a proper customer but only as another female body to ravish. In this part of the poem Rossetti gives a long description of the goblins' movements rather than a list of their fruit, which renders the goblins both beastly and alluring:

Laughed every goblin

When they spied her peeping:

Came towards her hobbling,

Flying, running, leaping,

Puffing and blowing,

Chuckling, clapping, crowing,

Clucking and gobbling,

Mopping and mowing, 
Chattering like magpies,

Fluttering like pigeons,

Gliding like fishes, -

Hugged her and kissed her,

Squeezed and caressed her: ...

Like the deluge of fruit at the beginning of the poem, the abundance of verbs following one another (mainly as participles) suggests a pornographic plenitude, and expresses the goblins' activity and sexual potency as opposed to Lizzie's apparent passivity and timidity. In this scene of abuse, her body becomes the locus on which the goblin men try to satisfy their appetite. Lizzie is intent on buying the fruit and leaving as soon as possible. However, when she insists on leaving, they assume a more threatening and aggressive attitude:

They trod and hustled her,

Elbowed and jostled her,

Clawed with their nails,

Barking, mewing, hissing, mocking,

Tore her gown and soiled her stocking,

Twitched her hair out by the roots,

Stamped upon her tender feet,

Held her hands and squeezed their fruits

Against her mouth to make her eat.

(11. 399-407)

As the last two lines suggest, the scene is not an innocent one as in a fable - on the contrary, it depicts sexual abuse. Like Alec in Thomas Hardy's Tess of the d'Urbervilles, who forces strawberries on the heroine, the goblin men act on sexual motives, and it is almost virtually a rape. The sexual import is also apparent in the successive use of action verbs. The description of Lizzie's resistance to eating the goblin fruit seems to be written in order to tone down this quasi-pornographic abundance through a series of similes:

White and golden Lizzie stood,

Like a lily in a flood, -

Like a rock of blue-veined stone

Lashed by tides obstreperously, -

Like a beacon left alone 
In a hoary roaring sea,

Sending up a golden fire, -

Like a fruit-crowned orange-tree

White with blossoms honey-sweet

Sore beset by wasp and bee, -

Like a royal virgin town

Topped with gilded dome and spire

Close beleaguered by a fleet

Mad to tug her standard down.

Here too, the poem continues to oscillate between a tale for adults and a children's tale. While "white and golden", "lily" and "virgin town" hint at a sense of innocence, the words and phrases following are full of sexual connotations. Lizzie is compared to "a lily in a flood" or a virgin town to be taken and shamed, both implying a sense of threat and doom. There is a sense of stoicism in her resistance to the goblin men and their fruit: "Lizzie uttered not a word; / Would not open lip from lip / Lest they should cram a mouthful in" (11. 430-32).

Since she is aware of the danger of being driven to death and illness like Jeanie and Laura, Lizzie does not totally yield to the goblins' lascivious call. She plays the game but at the same time cheats the goblins because she does not taste their fruit: "But laughed in heart to feel the drip / Of juice that syrupped all her face" (11. 433-34). She gets back her money, which the goblins have not accepted.

In the next scene, the female body encounters not the male body but another female one. When Lizzie comes home she shares the juice with her ailing sister so as to appease her hunger. The scene is full of associations of lesbian love:

[Laura] clung about her sister,

Kissed and kissed and kissed her:

Tears once again

Refreshed her shrunken eyes,

Dropping like rain

After long sultry drouth;

Shaking with anguish fear, and pain,

She kissed and kissed her with a hungry mouth.

(11. 485-92) 
While the encounters between the opposite sexes involve the use of physical force, this encounter between the two sisters suggests harmony, healing and regeneration. Although there is a kind of pleasure involved in the kissing of the sisters, Rossetti does not present it as pure pleasure since this erotic exchange is described in incongruous and contradictory terms: "the juice was wormwood to her tongue" and "[Laura] loathed the feast" (11. 494-95).

Through such oxymorons as a loathsome feast and juice like wormwood, the poet attempts to eradicate implications of lesbianism in the poem. Still, the effects of this seemingly innocent intimacy are indicative of orgasmic convulsions:

Writhing as one possessed she leaped and sung,

Rent all her robe, and wrung

Her hands in lamentable haste,

And beat her breast.

Her locks streamed like the torch

Borne by a racer at full speed,

Or like the mane of horses in their flight,

Or like an eagle when she stems the light

Straight toward the sun ....

(11. 496-504)

As in other crucial points in the poem, Christina Rossetti employs similes in succession to explicate the changes that Laura undergoes in her encounter with her sister's juice-immersed body. All these similes create a sense of indulgence in pleasure and breaking free from restraint, and their kissing and hugging each other imply a kind of sexual orgasm. When Laura is cured of her sickness, she asks herself "Is it death or is it life?" and comes to the conclusion that it is "Life out of death" (11. 52324). Despite her attempts to desexualize her narrative poem, Rossetti ends up implying that the predicament of the female body can be remedied through same-sex jouisance and solidarity.

Yet, at the end of the poem, the idea of the female body as capable of deriving sexual pleasure is discarded. The narrative re-introduces the sisters years later as mothers, with Laura telling the story to her daughters and nieces, with the reassuring refrain, "For there is no friend like a sister, / In calm or stormy weather" (11. 562-63).

Eventually, Laura and Lizzie emerge as conscious female subjects who have discovered the perils confronting the female body. Referring to 
Nancy Ziegenmeyer, a rape victim, whose story evolved into a book and film, Plummer suggests that sexual harassment may be turned into a means for finding a voice by women. ${ }^{14}$ Similarly, Rossetti transforms Laura into a narrator telling children what she and Lizzie experienced as young girls. This narrative twist turns the poem into a palindrome, in which the homodiegetic narrator retells a story which we readers have already heard. The palindromic nature of the narrative reduces the role of the poet, and the narrative turns into a text in which Laura tells the story without any mediation. Her poetic name, which is reminiscent of Dante's muse and the laurels worn by poets, attests her ability to author her own destiny despite adversities. Laura, in a sense, is like Scheherazade performing a vital function for survival. Thus, she helps build a tradition of awareness and resistance in her family.

“The Prince's Progress", written four years later in 1866, also deals with the issue of the female body. The poet does not allude to direct encounters between bodies of the opposite sexes as in "Goblin Market", and the female character does nothing but wait in a state of stupor. However, the female body is associated with flowers, gums and juices, which all suggest the female body and its erotic urges. The poem calls forth themes common to Chivalric Romances and courtly love poems such as the damsel in distress, and the knight setting out to save her. The opening of the poem heralds the existence of a pining lady who is waiting to be delivered from loneliness and distress:

Till all sweet gums and juices flow, Till the blossom of blossoms blow,

The long hours go and come and go,

The bride she sleepeth, waketh, sleepeth,

Waiting for one whose coming is slow:-

Hark! The bride weepeth.

Rossetti establishes the repertoire of the discourse she sets out to parody. The events in the story are unmistakably suggestive of a Quest Romance: the Prince confronts a milkmaid who attempts to deter him from his journey, a volcanic wasteland, an old man in a cave who makes him

${ }^{14}$ Ken Plummer, Telling Sexual Stories: Power, Change and Social Worlds, London, $1995,9$. 
work on a fire in return for a life potion, then he crosses a dangerous river, and finally comes to a green valley where his Bride lives. Nevertheless, through narrative and stylistic devices, this Romance is subjected to deliberate interrogation. As a narrative twist, the conclusion of the story renders the Prince's quest pointless since his beloved is dead. Rossetti also demeans the Prince and his deeds through an extensive use of adjectives that denote his inefficiency and fickleness. The Prince is presented as a satiric fiction, a parodic construction, whereas the Bride is a real woman, not an ideal, for she is mortal.

At the outset of his journey, the Prince seems nonchalant and drained of energy and he wastes his time fantasizing about the Bride by means of floral imagery:

"By her head lilies and rosebuds grow;

The lilies droop, will the rosebuds blow?

"Red and white poppies grow at her feet,

The blood-red wait for sweet summer heat,

Wrapped in bud-coats hairy and neat;

But the white buds swell, one day they will burst,

Will open their death-cups drowsy and sweet -

Which will open the first?"

The Bride is associated with drooping lilies, white poppies and blooming roses, which respectively connote virginity, innocence and sexual passion. At the end of his journey, the Prince muses about his Bride: "Rose, will she open the crimson core / Of her heart to him?" (11. 43637), which echoes Blake's erotically charged "Sick Rose", with its "bed / Of crimson joy". ${ }^{15}$

While the Bride is portrayed through erotically floral imagery, the Prince is associated with effeminacy and domesticity:

15 The Poems of William Blake, ed. W.H. Stevenson, text by David V. Erdman, Longmans' Annotated English Poets, London, 1971, 217. Rossetti employs the rose symbol also in a comparatively shorter narrative poem, "Brandon's Both", written in 1881 (The Complete Poems of Christina Rossetti, II, 168). 
In his world-end palace the strong Prince sat,

Taking his ease on cushion and mat,

Close at hand lay his staff and his hat.

This domesticity renders the Prince a laughing stock. He further loses his knightly traits when he is tempted by the milkmaid:

So he stretched his length in the apple-tree shade,

Lay and laughed and talked to the maid,

Who twisted her hair in a cunning braid

And writhed it in shining serpent-coils,

And held him a day and night fast laid

In her subtle toils.

Such details as the apple tree and serpentine hair allude of course to the temptation of Adam by Eve in the Garden of Eden. However, it is difficult to come to any conclusion as to whether the Prince is a ruthless womanizer, or a victim of the maid's erotic appeal. Although he seems to enjoy the maid's company he is far from being a seducer. Clearly he becomes the object of the maid's dominating sexual passion. Overpowered by a mere milkmaid, he proves to be both weak and disloyal.

In line with his inadequacy the tardy Prince is portrayed as "taking his ease on cushion and mat" (1. 13), "of purpose weak" (1. 47), a "sluggard" (1. 112), a "sleeper" (1. 117), "lagging ... and apt to swerve" (1. 301), "Lazy of limb" (1.302), loitering and indecisive. In a sense, in contrast to the goblins, he is impotent. Furthermore, he is presented as a ridiculous figure incapable of acting without any outside prompt. He is always reminded of his task by other characters or beasts, who act as a kind of chorus. At the beginning of the poem his attendants or subjects urge him to embark on his journey at once: " Time is short, life is short,' they took up the tale: / 'Life is sweet, love is sweet, use today while you may"' (11. 37-40). But these entreaties with their echoes of the carpe diem themetheir familiar reminder of the ephemeral nature of life, of the need to enjoy life's pleasures while there is still time, and the call to virgins to abandon their chaste state and enjoy love - is not directed at the virgin Princess. She is a mesh of fluids and passions and is ready "to seize the 
day". The appealing voices are directed at the Prince - summoning him to consummate his affair with his Bride.

The cave the Prince goes into can be interpreted as a metaphorical vagina, which he fails to penetrate in real life. He is like the old magician in the cave, who is too weak to move a finger. This elixir of life, which needs to be heated through bellowing, is, in a sense, the cure for his unmanliness. The potion is ready only after the old magician dies and his finger slips into the simmering water. This implies that it is not the Prince who manages to activate the potion of life and virility but the magician. If the finger is taken as a phallic symbol, once again the Prince's lack of sexual vigour is stressed.

The Prince's weakness is also apparent in his failure to cross the river, an action that once accomplished usually symbolizes sexual initiation and experience. In his attempt, he is almost drowned, which indicates his unmanliness. After the river incident, his attendants reprimand him once again for his tardiness: "The promise promised so long ago, / The long promise, has not been kept" (11. 381-82). The description of the Prince as a man lacking valour, strength, and sexual desire for his beloved produces a comic effect.

The Prince's next destination is a wasteland, which signals his barren sexuality, and foreshadows the Bride's demise. Finally he arrives at the Bride's palace only to find her already dead. The tragic death of the Bride changes the mood of the parody. Here, Christina Rossetti's voice becomes a critical one questioning the medieval idealization of women and their dependence on men.

The final criticism comes from the attendants of the late Bride:

"Too late for love, too late for joy,

Too late, too late!

You loitered on the road too long,

You trifled at the gate:

The enchanted dove upon her branch

Died without a mate;

The enchanted princess in her tower

Slept, died, behind the grate;

Her heart was starving all this while

You made it wait." 
These premonitory voices criticize the values propagated by the Chivalric Romance that assigns to women the role of enchanted and weak damsels waiting, often in vain, to be saved. Through the Prince's deeds these values are proved to be meaningless and ridiculous. Neither the Prince nor his Bride gains anything. The sexual and erotic energies of both of them are wasted.

In this poem Christina Rossetti's attitude towards the female body appears to be different from that in "Goblin Market" because here the Bride's apparent virginal state leads to her demise. Unlike Laura, who consumes her sexual desire through the agency of the goblin men, the Bride in "The Prince's Progress" is afflicted because all her life seems to depend on the arrival of her Prince, who is too weak to achieve anything. Like the Prince's lack of virility, the Bride's act of slavish waiting is laughable. ${ }^{16}$

Despite their seeming innocence and naivety, "Goblin Market" and "The Prince's Progress" harbour a strong strain of sexuality. Christina Rossetti expresses her views on the female body and sexuality through a repertoire of symbols that is built on fruit and flowers. It is difficult to pin down her attitude towards sex and sexuality, for she is an evasive and ambivalent poet who prefers to keep her secrets to herself as in "Winter: My Secret". ${ }^{17}$ Since writing on sex and sexuality in explicit terms was almost a taboo for Victorian female poets, Christina Rossetti's poems can be read as a double-voiced discourse, a palimpsest, containing a dominant as well as a muted story. While the dominant story conforms to traditional narratives and poetic genres, the muted one looms up revealing the kind of sexual issues that are deemed to be a taboo.

\footnotetext{
${ }^{16}$ Christina Rossetti's suspicion of sex and men finds its reverberations also in Speaking Likenesses (1874), a Lewis Carroll-like collection of children's tales. The book includes three embedded stories, which are told by a female adult to a group of little girls as at the end of "Goblin Market". In the first story Flora, the heroine, finds herself in an enchanted room where she is surrounded by three boys - Quills, Angles, and Hooks - and two girls. The boys are endowed with hard and erect bodies, while the girls have fluid bodies that allow no grasping. While the boys can play brutal games, the girls either become victims or passive objects at the mercy of the boys. Flora's body becomes a toy in the game called the Pincushion, which, interestingly, is a slang word for the pudenda. The game is built on the principle that the weakest player is to be chased and pierced with pins. The female body becomes the locus of male desire and harassment as in the case of Laura and Lizzie. This is further stated in another cruel game called Self-Help, in which "the boys were players, the girls played" (Selected Prose of Christina Rossetti, eds David A. Kent and P. G. Stanwood, New York, 1998, 132).

${ }^{17}$ The Complete Poems of Christina Rossetti, I, 47-48.
} 